\title{
Anti-lipase activity for Portulaca oleracea, Urtica urens, Brassica napus and Lathyrus hierosolymitanus wild plants from Palestine
}

Nidal JARADAT, Abdel Naser ZAID, Eyass Zuhair ZAGHAL

\begin{abstract}
Plants are used to the treatment and prevention of many of metabolic, degenerative and cardiovascular diseases. Obesity is one of the most common metabolic diseases which is considered one of the global health problems. The present study aimed to screen anti-lipase effect of Portulaca oleracea, Urtica urens, Brassica napus and Lathyrus hierosolymitanus traditional Palestinian medicinal wild plants. Anti-lipase activity was measured by using porcine pancreatic lipase inhibitory test which was established by using the UV-visible spectrophotometer method, while orlistat (anti-obesity drug) was used as a positive control reference. The porcine pancreatic lipase inhibitory effect for organic and aqueous extracts of Urtica urens were $157 \mu \mathrm{g} / \mathrm{ml}$ and $157.1 \mu \mathrm{g} / \mathrm{ml}$, respectively. While the
\end{abstract}

anti-lipase $\mathrm{IC}_{50}$ value for the organic extract of $P$. oleracea was $262.03 \mu \mathrm{g} / \mathrm{ml}$. In addition, the aqueous extracts of Brassica napus and Portulaca oleracea have anti-lipase activity with the $\mathrm{IC}_{50}$ values $296.87 \mu \mathrm{g} / \mathrm{ml}$ and $417.62 \mu \mathrm{g} / \mathrm{ml}$, respectively. Meanwhile, Lathyrus hierosolymitanus both aqueous and organic extracts were almost inactive. The results showed that Urtica urens, Portulaca oleracea, and Brassica napus have anti-lipase activity, which provided evidence for their folkloric use as functional food and medicine. These three plants could be used as antilipase agents in the pharmaceutical and nutritional industries or may be used as fatty food additives in order to decrease the absorption and digestion of fats from food.

Keywords: Obesity, pancreatic lipase enzyme, traditional plants.
Nidal Jaradat, Abdel Naser Zaid, Eyass Zuhair Zaghal

Department of Pharmacy, Faculty of Medicine and Health Sciences, An-Najah National University, Nablus, Palestine

Corresponding Author: Nidal Jaradat

e-mail: nidaljaradat@najah.edu

Submitted / Gönderilme: 23.03.2017 Revised / Düzeltme: 30.04.2017

Accepted / Kabul: $\quad 11.05 .2017$

How to cite this article: Jaradat N, Zaid AN, Zaghal EZ. Anti-lipase activity for Portulaca oleracea, Urtica urens, Brassica napus and Lathyrus hierosolymitanuswildplantsfromPalestine.MarmaraPharmJ2017;21(4):828-836

\section{INTRODUCTION}

Obesity is a serious worldwide health problem among adults and children due to the harms that it causes itself and due to its association with other medical threats, especially systemic hypertension, coronary heart disease, respiratory complications and type 2 diabetes mellitus in addition to its association with the increased incidence of some types of cancer. Furthermore, obesity has been a significant reason for the increasing health care costs. The prevalence of obesity is increasing in the recent years. Therefore, it is very important to find new ways to prevent and decrease the incidence of obesity. A number of strategies are used recently to treat and prevent obesity, just like diet and exercise. However, if these two strategies are not always beneficial then pharmacological treatment should be the next choice [1-4].

Since dietary lipids are considered a major source of unwanted calories, for this reason, the lipid metabolism should be elegantly balanced to maintain homeostasis, therefore, obesity occurs when this balance is lost. Certainly, 
controlling lipid metabolism by drugs is considered a possible way to treat obesity. Pancreatic and gastric lipases enzymes play an important role in the digestion and metabolism of dietary lipids. A semi-synthetic derivative of lipstatin, which is called Orlistat is a selective, potent inhibitor of the lipase enzyme [5-7].

Natural occurring phytochemicals which are especially obtained from traditional edible and medicinal plants are an opportunity for the investigation of novel anti-obesity substitutes of synthetic drugs [8].

Portulaca oleracea L. (Portulacaceae), which is commonly known as Pusley, Purslane, and Farfahinah or Baqlah in Palestine [9]. It is one of the most known edible and medicinal herb around the world which is widely distributed in the Middle East (Figure 1) and has many traditional medicinal uses such as antispasmodic, diaphoretic, and diuretic, as well as it is used in treatment of wound ulcers, dysuria, dysentery, liver complaints, scurvy, snakebites, bladder infections and many other pulmonary, urinary, and gastrointestinal tracts diseases $[10,11]$. In fact, it is used in the Palestinian folk medicine for treatment of obesity, diarrhea, stomachache, and diarrhea [12].

Urtica urens L. (Urticaceae), which is commonly known as Dwarf nettle, Ortiga, Ortigachica, Caáporopé and Qorres. It is an annual plant (Figure 1), which grows wildly in the wastelands, roadsides, and river banks. It is widely distributed in Asia, Africa, Europe, South America, and Australia [13].

In the folk medicine, aerial parts of $U$. urens are utilized in the Palestinian folk medicine as a diuretic, depurative, antidiabetic, antirheumatic and as an analgesic for muscle pain. In addition, it is used for the treatment of constipation, cough, prostatic inflammations, memory weakness, infertility and cancer [12]. Besides, it is included in many folkloric nutritious dishes and food preparations [14]. It is

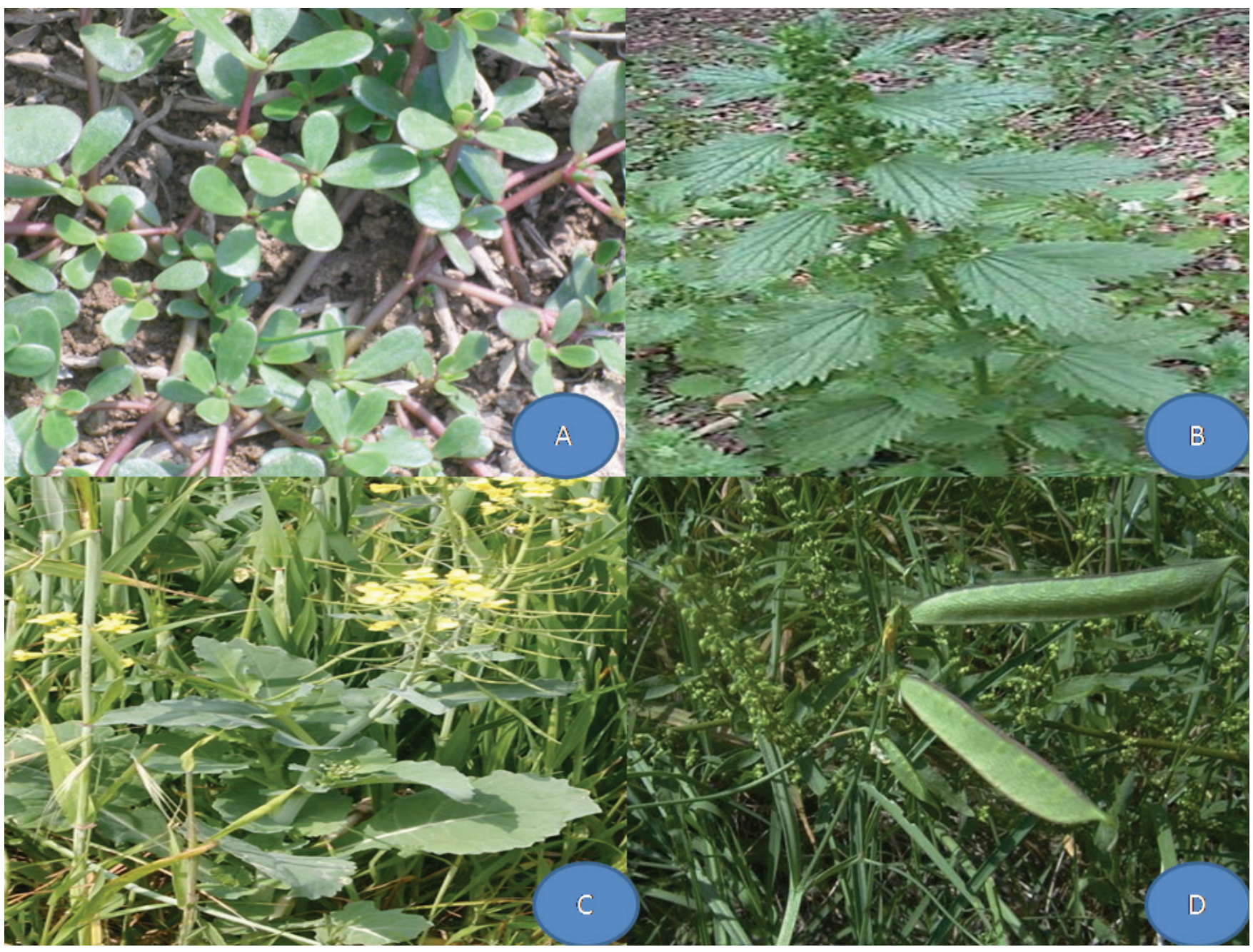

Figure 1. Portulaca oleracea (A), Urtica urens (B), Brassica napus (C) and Lathyrus hierosolymitanus (D). 
reported that $U$. urens extract had shown anti-bacterial, potential chemoprotective ability and possessed significant antinociceptive activities $[15,16]$. The leaves of $U$. urens contain alkaloids, saponins, phytate, and chlorogenic acid also rich in minerals as iron, manganese, zinc, copper, calcium, potassium, nitrogen, magnesium, phosphorus and sodium [14].

Brassica napus L., which is also called rapeseed, canola, rappi, oil seed, rappa or khardal. It is an annual herbaceous plant (Figure 1) which is a member of Brassicaceae family, that grows wildly in waste places and road-sided verges $[17,18]$.

The aerial parts of B. napus are used as a folkloric food in Palestine, and it is also used in the folk medicine in many countries for the treatment of cough, fever, and mucus [19]. The plant seeds are used in making edible oil, which is widely produced in Canada, China and India, which is considered the third-leading source of vegetable oil in the world after soybean and palm oil according to the United States Department of Agriculture [20, 21].

Brassica napus contains antioxidants such as flavonoids (flavones, flavonols), tannins and chalcones which are active against pancreatic lipase and can play a key role in obesity $[22,23]$. Moreover, it is also important to mention that, the animals which were fed on $B$. napus aerial parts suffered from weight loss [24].

Lathyrus hierosolymitanus Boiss (Papilionaceae), is an edible wild plant which is commonly known as Jerusalem vetchling. It is an annual climbing herb that is widely distributed in Palestine and Greece (Figure 1). It contains a mixture of flavonoids such as quercetin and Kaempferol and it is also used traditionally as a functional food for treatment of obesity and overweight [25-27].

Our investigation was intended to screen and to evaluate the anti-lipase effect of the aqueous and organic extracts of $P$. oleracea, B. napus, $U$. urens and L. hierosolymitanus. These four plants were chosen because they have been used traditionally from the ancient times as medicines and food.

\section{MATERIAL AND METHODS}

\section{Plants materials}

The aerial parts of P. oleracea, B. napus, $U$. urens and $L$. hierosolymitanus were collected in April 2016 from Palestine. These plants were identified in the Pharmacognosy and Phytochemistry Laboratory, Department of Pharmacy, Faculty of Medicine and Health Sciences, An-Najah National
University by the pharmacognosist Dr. Nidal Jaradat. The voucher specimen codes were "Pharm-PCT-1935, PharmPCT-407, Pharm-PCT-2562 and Pharm-PCT-1345", respectively.

The plant's aerial parts were washed and then dried in the shade at controlled temperature $\left(25 \pm 2^{\circ} \mathrm{C}\right)$ and humidity $(55 \pm 5 \mathrm{RH})$. The drying process took about two weeks until all the plant parts became well dried. After drying, the plant materials were grounded well by using a mechanical blender into a fine powder and transferred into airtight containers with proper labeling for future use.

\section{Instrumentation}

Shaker device (Memmert shaking incubator, Germany), rotary evaporator (Heidolph OB2000, Germany), spectrophotometer-UV-visible (Jenway 7135, England), grinder (Moulinex model, Uno, China), balance (Rad wag, AS 220/c/2, Poland) and freeze dryer (Mill rock technology BT85, china).

\section{Chemicals}

Dimethyl sulfoxide, p-nitrophenyl butyrate, orlistat, and tris$\mathrm{HCl}$ buffer were purchased from Sigma-Aldrich (Germany), while porcine pancreatic lipase type II was purchased from Sigma (USA), ethanol and acetone were bought from Lobachemie (India), hexane and acetonitrile were purchased from S.D Fine Chemicals (India).

\section{Preparation of plant extracts for Pancreatic Lipase Inhibition assay:}

A total of $25 \mathrm{~g}$ of the powdered plant was weighed and then exhaustively extracted by adding $150 \mathrm{ml}$ of $50 \%$ ethanol in distilled water and $100 \mathrm{ml}$ of $\mathrm{n}$-hexane. The mixture was then shaken for 48 hours at room temperature using a shaker device that was set at $200 \mathrm{rpm}$. Afterward, the mixture was filtered using suction filtration. The obtained filtrate was separated individually by using a separatory funnel into 2 phases; a lower aqueous phase and the upper organic phase. The remaining solid materials were re-extracted separately by $150 \mathrm{ml}$ of $50 \%$ ethanol in distilled water and the reextraction process was carried out as described above. The organic extracts were placed in the hood at $25^{\circ} \mathrm{C}$ to evaporate leftover organic solvents in order to become completely dry .Meanwhile, the aqueous extract was lyophilized using freeze dryer for 48 hours. 


\section{Pancreatic Lipase Inhibition}

The anti-lipase method was adapted from Bustanji et al. and Zheng et al. [28, 29] with some modifications. The plant extract stock solution $1000 \mu \mathrm{g} / \mathrm{ml}$ was dissolved in $10 \%$ DMSO, from which five different solutions were prepared in the following concentrations; 50, 100, 200, $300,400 \mu \mathrm{g} / \mathrm{ml}$, while $1 \mathrm{mg} / \mathrm{ml}$ stock solution of pancreatic lipase enzyme was prepared immediately before use which was suspended in tris- $\mathrm{HCl}$ buffer. A stock solution of p-nitrophenyl butyrate (PNPB) was prepared by dissolving $20.9 \mathrm{mg}$ in $2 \mathrm{ml}$ of acetonitrile. For each working test tube, $0.1 \mathrm{ml}$ of porcine pancreatic lipase $(1 \mathrm{mg} / \mathrm{ml})$ was added to a test tube containing $0.2 \mathrm{ml}$ from each diluted test-tubes containing $50,100,200,300,400 \mu \mathrm{g} / \mathrm{ml}$ of plants extracts. Tri-HCI solution was then added to the resulting mixture up to $1 \mathrm{ml}$ and incubated at $37^{\circ} \mathrm{C}$ for 15 minutes. After the incubation period, $0.1 \mathrm{ml}$ of $\mathrm{p}$-nitrophenyl butyrate solution was added to each test tube. The mixture was again incubated for 30 minutes at $37^{\circ} \mathrm{C}$. Pancreatic lipase activity was determined by measuring the hydrolysis of p-nitrophenolate to $\mathrm{p}$-nitrophenol at $405 \mathrm{~nm}$ using a $\mathrm{UV}$-visible spectrophotometer. The same procedure was repeated for aqueous, organic extracts and for Orlistat which was used as a reference control [30].

\section{RESULTS}

Eight aqueous and organic crude extracts were prepared from four plant species and their anti-lipase activity was investigated at a concentration of $1000 \mu \mathrm{g} / \mathrm{ml}$ for porcine pancreatic lipase inhibition. The inhibitory activities towards pancreatic lipase are reported in Table 1. Throughout the investigated results, the aqueous and organic extracts of $U$. urens have $\mathrm{IC}_{50} 157 \mu \mathrm{g} / \mathrm{ml}$ and $157.1 \mu \mathrm{g} / \mathrm{ml}$, respectively. This showed the highest porcine pancreatic lipase inhibitory effects between all the studied extracts. Meanwhile, the aqueous and organic extracts of L. hierosolymitanus showed the lowest porcine pancreatic lipase inhibitory effects between all the studied plant's extracts.

In addition to that, the studied extracts anti-lipase $\mathrm{IC}_{50}$ 's were compared with the standard reference Orlistat, which has anti-lipase $\mathrm{IC}_{50}$ value $12.38 \mu \mathrm{g} / \mathrm{ml}$. The results of the antilipase activity of the four studied plants species are shown in Table 1 and in the Figures 2-5.

Table 1. Porcine pancreatic lipase inhibitory properties, expressed as $\mathrm{IC}_{50}(\mu \mathrm{g} / \mathrm{ml})$, of the aqueous and organic extracts of 4 plant species and their yields percentages.

\begin{tabular}{|c|c|c|c|c|c|}
\hline Plants names & Arabic name & $\begin{array}{l}\mathrm{IC}_{50} \\
\text { Organic } \\
\text { extract, } \\
\mu \mathrm{g} / \mathrm{ml}\end{array}$ & $\begin{array}{l}\text { Organic } \\
\text { extract } \\
\text { yield, \% }\end{array}$ & $\begin{array}{l}\mathrm{IC}_{50} \\
\text { Aqueous } \\
\text { extract, } \\
\mu \mathrm{g} / \mathrm{ml}\end{array}$ & $\begin{array}{l}\text { Aqueous extract } \\
\text { yield, } \%\end{array}$ \\
\hline Urtica urens & Qorres & 157 & 1.46 & 157.1 & 13.5 \\
\hline Portulaca oleracea & Farfahinah & 262.03 & 0.65 & 417.62 & 18.25 \\
\hline Brassica napus & khardal bari & 3301.41 & 2.35 & 296.87 & 8.5 \\
\hline Lathyrus hierosolymitanus & $\begin{array}{l}\text { Jelban } \\
\text { Al-Quds }\end{array}$ & 125825.6 & 1.4 & 17477.73 & 11.85 \\
\hline
\end{tabular}




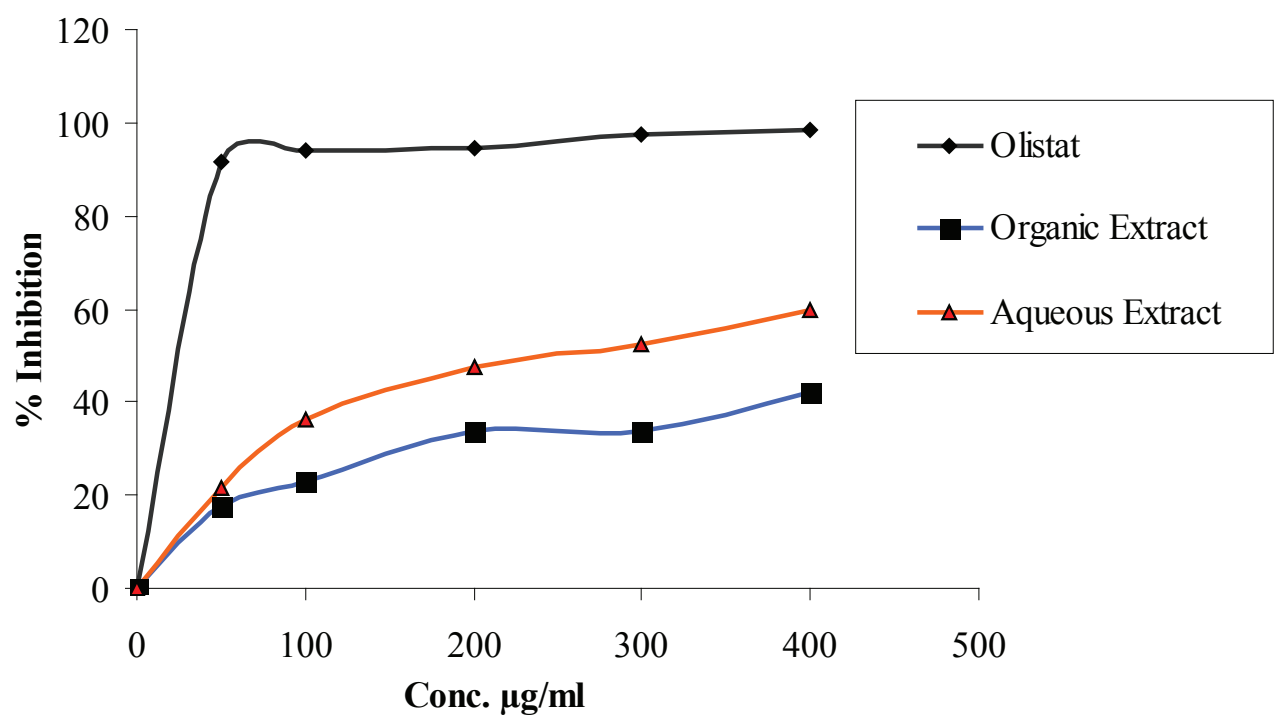

Figure 2. The inhibitory effect of the aqueous and organic extracts of B. napus and orlistat on the activity of porcine pancreatic lipase.

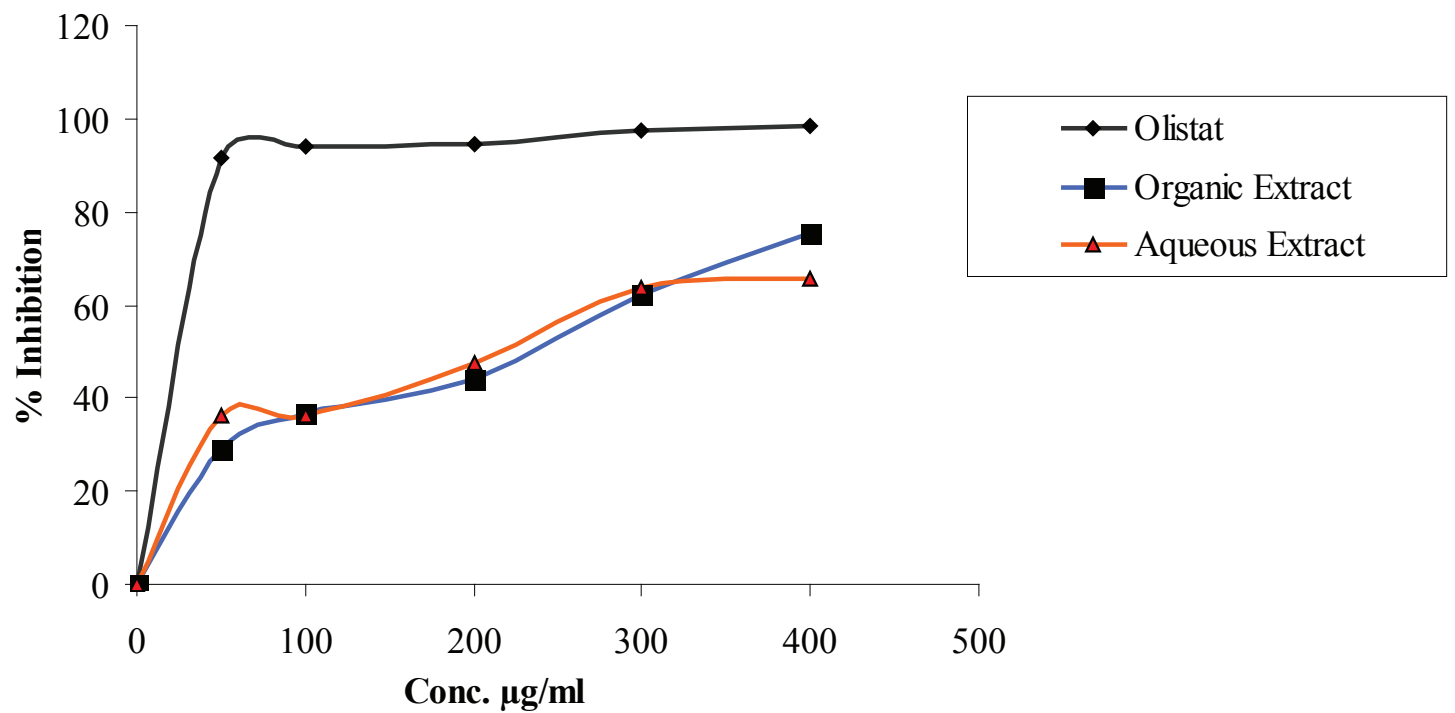

Figure 3. The inhibitory effect of the aqueous and organic extracts of. $U$. urens and orlistat on the activity of porcine pancreatic lipase. 


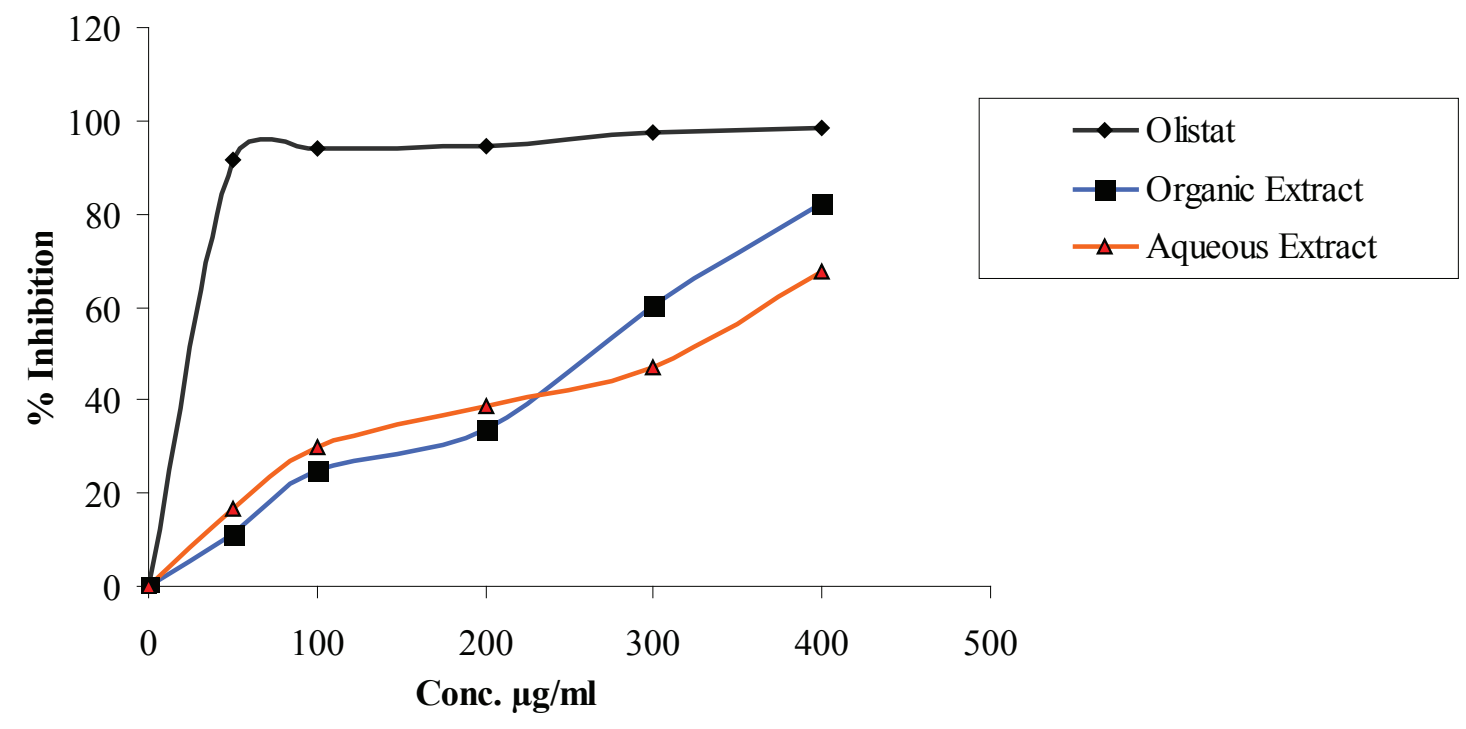

Figure 4. The inhibitory effect of the aqueous and organic extracts of P. oleracea and orlistat on the activity of porcine pancreatic lipase.

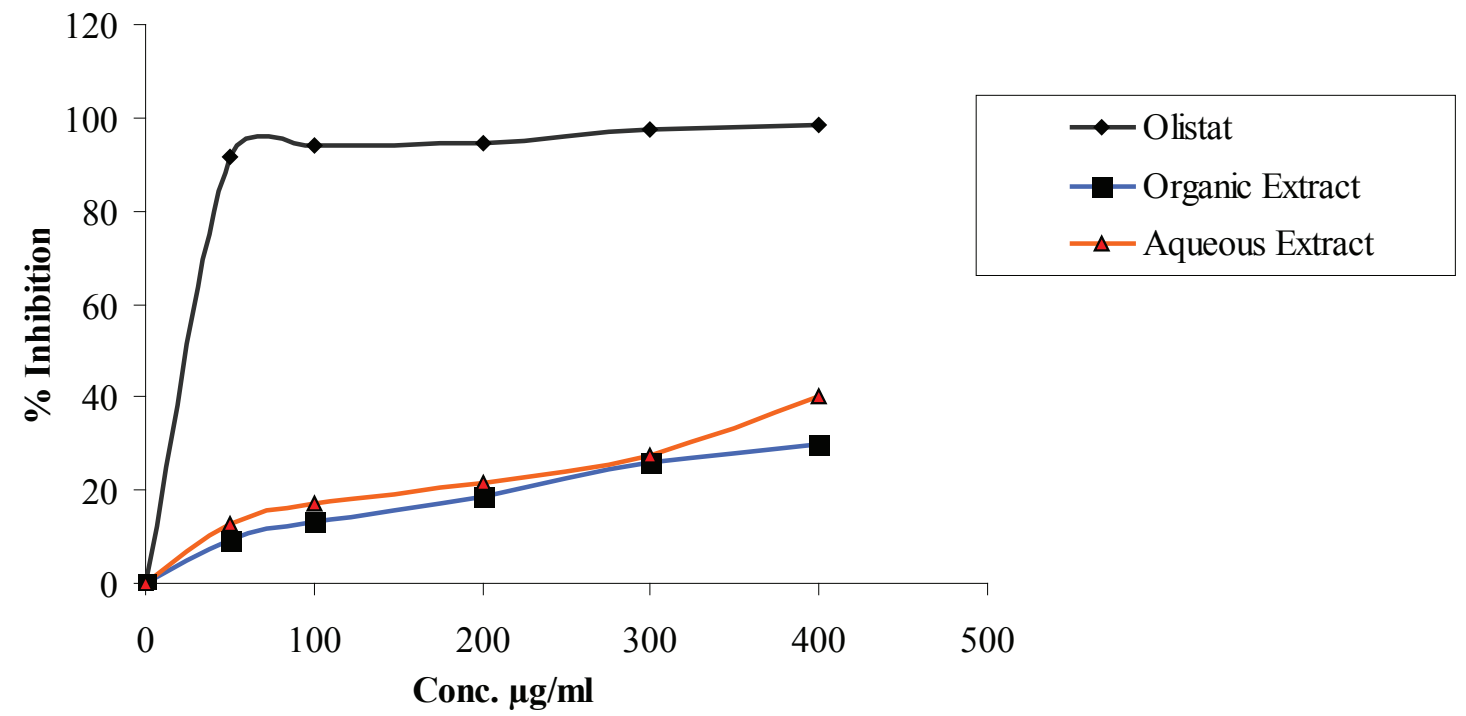

Figure 5. The inhibitory effect of the aqueous and organic extracts of L. hierosolymitanus and orlistat on the activity of porcine pancreatic lipase. 


\section{DISCUSSION}

Metabolic disorders such as obesity, overweight, hyperlipidemia; are increasing globally at alarming rates and became a main public health concern with immeasurable social and economic costs. In fact there is a clear correlation between obesity and chronic diseases such as osteoarthritis, hypertension, diabetes, cardiac arrest and some types of cancer. Plus it's clear that the obese people are more likely to use the health care institutes more than others especially in developing countries [31-33].

Plant kingdom provided an endless source of dietary phytochemicals with potential anti-obesity activity [34] and the pharmaceutical companies have invested many efforts in producing anti-obesity agents especially in the developed countries. Unfortunately, only one agent with anti-lipase activity which was isolated from an actinobacterium is clinically registered and approved in Europe for the treatment of overweight and obesity [35]. This compound inhibited the activity of porcine pancreatic lipase enzyme which involved in fat digestion. Recently, hundreds of natural compounds are currently being isolated from plants, bacteria, fungi, and algae which were screened for their anti-lipase activity. Among them, extracts isolated from common foods such as apple, grape, ginseng, peanut, tea, yerba mate, and soybeans have been documented. Saponins and polyphenols have an inhibitory effect on pancreatic lipase activity, which could be utilized in the treatment of the obesity [36]. Moreover, characterization of the anti-lipase phytogenic agents provided a significant role not only in controlling obesity and overweight but also for managing some of lifestyle-related diseases [4]. In fact, these phytogenic products worked as antiobesity agents by different mechanisms of actions such as; reducing adipose tissue mass by inhibiting the proliferation of precursor cells, increasing rates of apoptosis during the adiposity lifecycle, and by inhibiting of the absorption of dietary lipids by reducing the pancreatic lipase enzyme formation $[4,6,37]$.

Polyphenolics is a class of phytochemical which approved its anti-obesity effect. This class including phenolic acids such as gallic, coumaric, caffeic, and chlorogenic acids and flavonoids. Unfortunately, the pharmacological effects of these polyphenols on human adipocytes have not been studied systematically [38].

The $U$. urens leaves contain saponin glycoside which has proven its ability to inhibit pancreatic lipase enzyme and thus, it may represent an effective treatment for obesity [6]. However, according to a study which was conducted by Gholamhoseinian et al. the inhibition percentage of $U$. urens against pancreatic lipase was $44.7 \%$ by using turbidimetric method (39).

In a study which was conducted by Kim et al. (2012), about the anti-lipase effect of Brassica juncea leaves, which showed that it has an $\mathrm{IC}_{50}$ more than $100 \mu \mathrm{g} / \mathrm{ml}(40)$.

Evaluating the obtained results, it was found that five of these plant extracts (Table 1) were able to inhibit the lipase enzyme in a dose-dependent manner, with an $\mathrm{IC}_{50}$ range of 157.0 $417.62 \mu \mathrm{g} / \mathrm{ml}$. The best anti-lipase activity were obtained for the organic and aqueous extracts of $U$. urens which were 157 $\mu \mathrm{g} / \mathrm{ml}$ and $157.1 \mu \mathrm{g} / \mathrm{ml}$, respectively followed by the organic extracts of $P$. oleracea which has $\mathrm{IC}_{50} 262.03 \mu \mathrm{g} / \mathrm{ml}$ and the aqueous extract of $B$. napus and $P$. oleracea that have $\mathrm{IC}_{50}$ $296.87 \mu \mathrm{g} / \mathrm{ml}$ and $417.62 \mu \mathrm{g} / \mathrm{ml}$, respectively. Meanwhile, the organic extract of $B$. napus also the aqueous and organic extracts of L. hierosolymitanus were inactive.

Further phytochemical studies required to isolate antilipase molecules from these plants also pharmacological studies needed to investigate the mechanism of action for the obtained compounds. In addition, in-vivo clinical studies required to investigate their effects directly in the obese patients.

\section{Limitations}

We could not isolate the main component in our plants due to unavailability of HPLC-MS in our university, also we cannot establish in-vivo anti-lipase effect on human due to the lack of funding.

\section{CONCLUSION}

The exploration of active anti-obesity drugs from natural sources may provide a new pathway for manufacturing a novel safe and effective pharmacological, nutraceutical or pharmaceutical agent for treatment of obesity. Moreover, these promising active plants are considered valuable as a starting material for further isolation, identification and characterization of phyto-active compounds for developing anti-lipase functional drugs.

\section{Conflicts of interest statement}

None of the authors had any financial or personal relationships with other individuals or organizations that might inappropriately influence their work during the submission process. 


\section{References}

1. James PT, Leach R, Kalamara E, Shayeghi M. The worldwide obesity epidemic. Obes Res 2001;9:228-33.

2. Jaradat N, Zaid AN, Hussein F, Ali I. The effects of preservation methods of grapevine leaves on total phenols, total flavonoids, and antioxidant activity. Marmara Pharm J 2017;21: 291-7.

3. Tapsell L, Batterham M, Thorne R, O'shea J, Grafenauer SJ, Probst Y. Weight loss effects from vegetable intake: A 12-month randomised controlled trial. Eur J Clin Nutr 2014; 68: 778-85.

4. Williams DJ, Edwards D, Hamernig I, Jian L. Vegetables containing phytochemicals with potential anti-obesity properties: A review. Food Res Int 2013; 52: 323-33.

5. Saravanan G, Ponmurugan P, Deepa MA, Senthilkumar B. Anti-obesity action of gingerol: Effect on lipid profile, insulin, leptin, amylase, and lipase in male obese rats induced by a high-fat diet. J Sci Food Agr 2014; 94: 2972-7.

6. Birari RB, Bhutani KK. Pancreatic lipase inhibitors from natural sources: Unexplored potential. Drug Discov Today 2007; 12: 879-89.

7. Castro M, Preto M, Vasconcelos V, Urbatzka R. Obesity: The metabolic disease, advances on drug discovery and natural product research. Curr Top Med Chem 2016;16: 2577-604.

8. Zar Kalai F, Han J, Ksouri R, El Omri A, Abdelly C, Isoda H. Antiobesity effects of an edible halophyte Nitraria retusa forssk in 3T3-L1 preadipocyte differentiation and in C57B6J/L mice fed a high fat diet-induced obesity. Evid Based Complementary Altern Med 2013; 2013:1-7.

9. Rashed A, Afifi F, Disi A. Simple evaluation of the wound healing activity of a crude extract of Portulaca oleracea L. (growing in Jordan) in Mus musculus JVI-1. J Ethnopharmacol 2003; 88: 131-6.

10. Kotb FT. Medicinal plants in Libya. Arab encyclopedia house, Tripoli. 1985.

11. Hussein MA. Purslane extract effects on obesity-induced diabetic rats fed a high-fat diet. Malays J Nutr 2010; 16: 41929.

12. Ali-Shtayeh M, Jamous RM. Traditional arabic Palestinian herbal medicine, TAPHM. Palestine: Biodiversity and Environmental Research Center, BERC; 2008.

13. Tuzlacı E, Aymaz PE. Turkish folk medicinal plants. Fitoterapia 2001; 72: 323-43.

14. Marrassini C, Acevedo C, Miño J, Ferraro G, Gorzalczany $\mathrm{S}$. Evaluation of antinociceptive, antinflammatory activities and phytochemical analysis of aerial parts of Urtica urens $\mathrm{L}$. Phytother Res 2010; 24: 1807-12.

15. Jimoh F, Adedapo A, Aliero A, Afolayan A. Polyphenolic and biological activities of leaves extracts of Argemone subfusiformis (Papaveraceae) and Urtica urens (Urticaceae). Rev Biol Trop 2010; 58: 1517-31.

16. Ozkarsli M, Sevim H, Sen A. In vivo effects of Urtica urens (dwarf nettle) on the expression of CYP1A in control and 3-methylcholanthrene-exposed rats. Xenobiotica 2008; 38: 48-61.

17. Raman H, Raman R, Eckermann P, Coombes N, Manoli S, Zou X, Edwards D, Meng J, Prangnell R, Stiller J, Batley J, Luckett D, Wratten N, Dennis E.Genetic and physical mapping of flowering time loci in canola (Brassica napus L.). Theor Appl Genet 2013; 126: 119-32.

18. Parnell J, Doogue D, Webb DA. Webb's an Irish flora. Cork University Press, Ireland. 2012.

19. Lim TK. Edible medicinal and non-medicinal plants. Springer, USA. 2012.

20. Rahmatullah M, Ishika T, Rahman M, Swarna A, Khan T, Monalisa MN, Seraj S, Mou SM, Mahal MJ, Biswas KR. Plants prescribed for both preventive and therapeutic purposes by the traditional healers of the Bede community residing by the Turag River, Dhaka district. Am-Eurasian J Sustain Agric 2011; 5: 325-31.

21. Ali-Shtayeh MS, Jamous RM, Al-Shafie' JH, Elgharabah WA, Kherfan FA, Qarariah KH, Khdair IS, Soos IM, Musleh AA, Isa BA, Herzallah HM, Khlaif RB, Aiash SM, Swaiti GM, Abuzahra MA, Haj-Ali MM, Saifi NA, Azem HK, Nasrallah HA.Traditional knowledge of wild edible plants used in Palestine (Northern West Bank): a comparative study. J Ethnobiol Ethnomed 2008; 4: 1-13.

22. Batista C, Barros L, Carvalho AM, Ferreira IC. Nutritional and nutraceutical potential of rape (Brassica napus L. var. napus) and "tronchuda" cabbage (Brassica oleraceae L. var. costata) inflorescences. Food Chem Toxicol 2011; 49: 1208-14.

23. Mhatre SV. Pancreatic lipase inhibitor from food plant: Potential molecule for development of safe anti-obesity drug. GMG J Med Sci 2013; 3: 34-41.

24. Johns T, Kitts W, Newsome F, Towers GN. Anti-reproductive and other medicinal effects of Tropaeolum tuberosum. J Ethnopharmacol 1982; 5: 149-61.

25. White R. International Legume Database \& Information Service. ILDIS, UK. 2005.

26. Syouf MQ. Lathyrus genetic resources in Asia. Natural distribution and utilization of Lathyrus in Jordan. International Plant Genetic Resources Institute, Washington. 1996, pp 6781.

27. Ranabahu P, Harborne JB. The flavonoids of the genus Lathyrus and a comparison of flavonoid patterns within the tribe vicieae. Biochem Syst Ecol 1993; 21: 715-22.

28. Bustanji $\mathrm{Y}$, Issa $\mathrm{A}$, Mohammad M, Hudaib M, Tawah K, Alkhatib H, Almasri I, Al-Khalidi B. Inhibition of hormone sensitive lipase and pancreatic lipase by Rosmarinus officinalis extract and selected phenolic constituents. J Med Plant Res 2010; 4: 2235-42.

29. Zheng C-D, Duan Y-Q, Gao J-M, Ruan Z-G. Screening for anti-lipase properties of 37 traditional Chinese medicinal herbs. J Chin Med Assoc 2010; 73: 319-24.

30. Jaradat NA, Zaid AN, Hussein F. Investigation of the antiobesity and antioxidant properties of wild Plumbago europaea and Plumbago auriculata from North Palestine. Chem Biol Technol Agr 2016; 3: 31-7.

31. Popkin BM. The world is fat: The fads, trends, policies, and products that are fattening the human race. Penguin group, New York. 2009.

32. Marinou K, Tousoulis D, Antonopoulos AS, Stefanadi E, Stefanadis C. Obesity and cardiovascular disease: From pathophysiology to risk stratification. Int J Cardiol 2010; 138:3-8. 
33. Piper AJ. Obesity hypoventilation syndrome-the big and the breathless. Sleep Med Rev 2011; 15: 79-89.

34. Nuutila AM, Puupponen-Pimiä R, Aarni M, OksmanCaldentey K-M. Comparison of antioxidant activities of onion and garlic extracts by inhibition of lipid peroxidation and radical scavenging activity. Food Chem 2003; 81: 485-93.

35. Krentz AJ, Fujioka K, Hompesch M. Evolution of pharmacological obesity treatments: focus on adverse sideeffect profiles. Diabetes Obes Metab 2016; 18: 558-70.

36. De la Garza AL, Milagro FI, Boque N, Campión J, Martínez JA. Natural inhibitors of pancreatic lipase as new players in obesity treatment. Planta Med 2011; 77: 773-85.
37. Yun JW. Possible anti-obesity therapeutics from nature-A review. Phytochemistry 2010; 71: 1625-41.

38. Morikawa K, Ikeda C, Nonaka M, Suzuki I. Growth arrest and apoptosis induced by quercetin is not linked to adipogenic conversion of human preadipocytes. Metabolism 2007; 56: 1656-65.

39. Gholamhoseinian A, Shahouzehi B, Sharifi-Far F. Inhibitory effect of some plant extracts on pancreatic lipase. IJP-Inter J Pharmacol 2010; 6: 18-24.

40. Kim YS, Lee Y, Kim J, Sohn E, Kim CS, Lee YM, Jo K, Shin S, Song Y, Kim JH, Kim JS. Inhibitory activities of Cudrania tricuspidata leaves on pancreatic lipase in vitro and lipolysis in vivo. Evid Based Complementary Altern Med 2012; 2012: 1-6. 